\title{
Studi Ketertarikan Masyarakat Terhadap Penggunaan Aplikasi Tangerang Live (Pendekatan Pada Teori Skala SERVQUAL)
}

\author{
Fidellis Wato Tholok ${ }^{1}$ \\ Sonny Santosa ${ }^{2}$ \\ Suhendar Janamarta ${ }^{3}$ \\ Manajemen, Universitas Buddhi Dharma, Banten, Indonesia
}

\begin{abstract}
Abstrak
Aplikasi Tangerang Live merupakan aplikasi berbasis android yang dikenalkan oleh Pemerintan Kota Tangerang untuk membantu masyarakat Tangerang mengefisensi dan mengefektifkan proses administrasi yang mungkin dibutuhkan oleh masyarakat Tangerang. Penelitian ini dilakukan dengan tujuan untuk mengukur sebuah model kualitas layanan jasa atas sebuah aplikasi yang dikeluarkan oleh Pemerintah Kota Tangerang dan faktor penerimaan teknologi yang baru ini berdasarkan persepsi pengguna dan melihat pengaruh kualitas layanan aplikasi tersebut dengan pendekatan pada teori Skala SERVQUAL dalam kaitannya dengan faktor meningkatkan kualitas jasa. Uji hubungan antara variabel kualitas terhadap keputusan penggunaan dilakukan dengan analisis regresi linear berganda. mengambil sampel obyek penelitian pada mahasiswa program studi manajemen Di Universitas Buddhi Dharma sejumlah 68 responden yang memenuhi syarat untuk diteliti lebih lanjut dengan alat uji statistik SPSS. Hasil penelitian menjelaskan bahwa rata-rata nilai kualitas adalah sebagai berikut : pertama, kualitas layanan situs pada aplikasi memiliki dampak yang cukup signifikan terhadap keputusan penggunaan aplikasi, kedua, layanan dasar situs pada aplikasi memiliki dampak cukup signifikan terhadap keputusan penggunaan aplikasi yang berimplikasi pada peningkatan kualitas layanan jasa itu sendiri. Hal ini sejalan dengan hasil dari metode analisis yang digunakan dalam regresi linear sederhana dengan hasil variabel $\mathrm{X} 1$ terhadap $\mathrm{Y}$ adalah $\mathrm{Y}=\mathbf{2 0 , 3 4 9}+\mathbf{0 , 4 7 7} \mathrm{X}$ 1 lalu untuk hasil variabel $\mathrm{X} 2$ terhadap $Y$ adalah $Y=18,699+\mathbf{0 , 5 3 5} X \mathbf{2}$ dan regresi linear berganda dengan hasil variabel X1, X2 terhadap $Y$ adalah $Y=14,036+0,373$ X1 + 0,272 X2.

Selain itu besaran pengaruh juga didapat dari hasil metode analisis koefisien determinasi, hasilnya $\mathrm{X} 1$ memiliki pengaruh kontribusi terhadap $\mathrm{Y}$ sebesar 30,8\%, X2 memiliki pengaruh kontribusi terhadap $Y$ sebesar 20,9\%, X1,X2 memiliki pengaruh kontribusi terhadap $Y$ sebesar 34,7\%, hal ini menandakan bahwa studi ini memiliki kontribusi yang cukup signifikan terhadap kaitannya dengan peningkatan kualitas jasa.
\end{abstract}

Kata Kunci : Aplikasi Tangerang Live, Kualitas layanan, Keputusan Penggunaan, Skala SERVQUAL 


\begin{abstract}
Tangerang Live application is an android-based application introduced by the Government of Tangerang City to help the Tangerang community to streamline and streamline administrative processes that may be needed by the Tangerang community. This research was conducted with the aim of measuring a service quality model of an application issued by the Tangerang City Government and this new technology acceptance factor based on user perceptions and looking at the effect of application service quality with approaches to the SERVQUAL Scale theory in relation to quality improvement factors services. Test the relationship between the quality variables on the decision to use is done by multiple linear regression analysis. taking samples of research objects in management study program students At Buddhi Dharma University a number of 68 respondents who met the requirements for further investigation with the SPSS statistical test tool. The results of the study explain that the average value of quality is as follows: first, the quality of site services on the application has a significant impact on the decision to use the application; service itself. This is in line with the results of the analysis method used in simple linear regression with the results of $X 1$ towards $Y$ is $Y=20,349+0,477 X 1$ then for the results of variable X2 to $Y$ are $Y=18,699+0,535 X 2$ and multiple linear regression with the results of variable $X 1, \quad X 2$ against $Y$ is $Y=14.036+0.373 X 1+0.272 X 2$. Besides the magnitude of the influence is also obtained from the results of the coefficient of determination analysis method, the result X1 has the effect of contribution to $Y$ of $30.8 \%, X 2$ has the influence of contribution to $Y$ of $20.9 \%, X 1$, X2 has the effect of contribution to $Y$ of $34.7 \%$, this indicates that this study has a significant contribution to the relation to improving service quality.
\end{abstract}

Keywords: Tangerang Live application, service quality, usage decision, SERVQUAL scale

\title{
Pendahuluan
}

Dilansir dari sebuah situs resmi (setkab.go.id, 2017) Pemerintah Pusat menyinggung visi Indonesia Emas 2045 dimana saat itu Indonesia bercita-cita untuk menjadi negara dengan kekuatan ekonomi terbesar ke 4 di dunia, untuk mendukung pencapaian cita-cita tersebut maka diperlukan salah satunya adalah dengan peningkatan pelayanan publik, sebagai contohnya penataan administrasi kependudukan menekankan pentingnya pelayanan yang diberikan dengan cepat, pelayanan cepat disebutnya merupakan suatu urgensi karena sudah bersentuhan langsung dengan kebutuhan masyarakat. Melihat fenomena tersebut maka sangat diperlukan adanya teknologi yang bisa diandalkan, kita bisa melihat bahwa perkembangan teknologi di era millenium ini selain memiliki fitur yang sangat canggih, dapat juga memiliki manfaat lain, hal ini sangat lumrah sebagai gambaran yang dihasilkan mengingat perkembangan pengetahuan dan teknologi semakin cepat pertumbuhannya. Tak ayal hal ini menimbulkan tidak hanya dampak positif seperti yang disebutkan diatas, tetapi juga dampak negative seperti keberadaan manusia yang semakin tergantikan dengan teknologi yang ada.

Program pemerintah sebagai kota yang cerdas pun tidak lepas dari perkembangan teknologi informasi dan komunikasi, pegawai diajak untuk 
mengenal dan belajar teknologi informasi komunikasi, dengan adanya perkembangan teknologi informasi komunikasi, metode-metode yang lama akan tergantikan dengan metode yang baru. Kita harus siap dalam menghadapi globalisasi yang terus menuntu manusia untuk mempelajari dan mengikutinya, karena manusia yang maju adalah manusia yang mau mengikuti perkembangan zaman dan siap untuk menerimanya. Sampai dengan maret 2019, aplikasi berbasis android yang terdahtar di google play store mencapai titik 2.6 juta (https://www.statista.com/, 2019). Berbagai jenis aplikasi tersedia didalamnya mulai dari permainan, buku, aplikasi chat, musik, majalah dan TV. Sebagian besar aplikasi yang tersedia dilayanan tersebut adalah gratis, namun para perusahaan pembuat aplikasi memiliki model bisnis tersendiri untuk tetap mendapatkan keuntungan.

Salah satu aplikasi yang terdaftar di google play store adalah aplikasi Tangerang Live. Aplikasi Tangerang Live adalah aplikasi berbasi android yang menyediakan layanan daring untuk membantu masyarakat dalam pelayanan publik seperti kependudukan, pendidikan, serta akses kesehatan yang ad di Tangerang. Aplikasi Tangerang Live ini diluncurkan oleh Pemerintah Kota Tangerang pada hari rabu tanggal 17 agustus 2016 (https://tangerangkota.go.id, 2016) sebagai bentuk pelaksanaan dari pelayanan publik yang optimal sesuai dengan yang tertuang dalam Peraturan No. 63/KEP/M.PAN/7/2003 (https://peraturan.bkpm.go.id, 2011). Terwujudnya pelayanan publik yang berkualitas merupakan salah satu ciri Kepemerintahan Yang Baik sebagai tujuan dari pendayagunaan aparatur negara. Disadari bahwa kebijakan pendayagunaan apartur negara khususnya dalam peningkatan kualitas pelayanan publik, senantiasa harus memperhatikan tuntutan dan dinamika masyarakat yang berada dalam suasana reformasi, demokratisasi, desentralisasi, otonomi daerah dan penegakan HAM, termasuk antisipasi terhadap kemajuan Iptek.

Aplikasi Tangerang Live sampat saat ini telah diunduh oleh kurang lebih 50 ribu pengguna, jumlah yang sudah mulai menunjukkan peningkatan pengguna jika dibandingkan pada tahun pertama diluncurkan oleh Pemerintah Kota Tangerang (https://tangerangkota.bps.go.id, 2018), peningkatan tingkat penggunaan aplikasi oleh pengguna akhir dipengaruhi oleh kualitas layanan yang tersedia didalam aplikasi tersebut. Dinas komunikasi dan informatika Kota Tangerang selalu gencar mensosialisasikan portal aplikasi layanan publik yang dinamakan Tangerang Live, selain itu adanya penambahan menu pada aplikasi seperti jadwal KA commuter line, dan perijinan online juga cukup membuat masyarakat semakin antusias untuk menggunakan aplikasi ini dalam memperoleh pelayanan publik yang dibutuhkan (https://tangerangkota.go.id, 2019).

Untuk mengevaluasi kualitas aplikasi, peneliti melakukan pendekatan pada teori Skala SERVQUAL (Keller, 2009), hal ini didasari oleh alasan bahwa dalam teori tersebut ada indikator yang cukup dapat dijadikan batasan dalam mengukur kualitas jasa terutama pada aplikasi Tangerang Live, sehingga bagi tim peneliti hal ini menjadi satu pendekatan yang memiliki kekhasan dalam mengupas inti sari dari sebuah kualitas jasa. selain itu, pendekatan yang digunakan dalam penelitian ini belum pernah digunakan dalam mengukur kualitas website (aplikasi) komersial, oleh karena itu, perlu dilakukan penelitian terhadap pendekatan teori ini (Leonard 
L Berry, A Parasuraman, dan Valerie A Zeithami, 2009) tentang penerapan teori tersebut pada aplikasi smartphone berbasis android untuk menilai apakah teori ini valid digunakan untuk menilai kualitas pada layanan teknologi informasi dan komunikasi lainnya selain website. Oleh karena itu dalam penelitian ini, tim peneliti ingin menguji apakah terdapat pengaruh antara kualitas layanan aplikasi Tangerang Live sebagai ketertarikan masyarakat itu sendiri terhadap penggunaan aplikasi tersebut.

\subsection{Hasil dan Pembahasan}

Variabel penelitian dan indikator yang digunakan pada penelitian ini ditampilkan pada Tabel 1.

Tabel 1.

Variabel Penelitian dan Indikatornya

\begin{tabular}{|c|c|c|c|}
\hline Variabel & Sub Variabel & Indikator & Sumber \\
\hline \multirow{7}{*}{$\begin{array}{l}\text { Kualitas } \\
\text { Layanan (X1) }\end{array}$} & \multirow{7}{*}{$\begin{array}{ll} & \text { ATRIBUT } \\
\text { SERVQUAL (SERV) } \\
\text { 1. Keandalan } \\
\text { 2. Responsivitas } \\
\text { 3. Jaminan } \\
\text { 4. Empati } \\
\text { 5. Wujud }\end{array}$} & Manfaat yang didapat & \multirow{7}{*}{ (Kotler, 2009) } \\
\hline & & Kemudahan Penggunaan & \\
\hline & & Sikap Pengguna Akhir & \\
\hline & & $\begin{array}{l}\text { Niat untuk menggunakan } \\
\text { aplikasi }\end{array}$ & \\
\hline & & Penggunaan aktual. & \\
\hline & & Tingkat kepercayaan & \\
\hline & & Persepsi jaminan & \\
\hline \multirow{4}{*}{$\begin{array}{l}\text { Layanan } \\
\text { Dasar }(X 2)\end{array}$} & \multirow{4}{*}{$\begin{array}{l}\text { Layanan aplikasi } \\
\text { (LA) }\end{array}$} & Norma Subyektif & \multirow{4}{*}{ (Kotler, 2009) } \\
\hline & & Dukungan Pemerintah. & \\
\hline & & Informasi yang uptodate & \\
\hline & & Tampilan image & \\
\hline $\begin{array}{l}\text { Tingkat } \\
\text { Ketertarikan } \\
\text {-Persepsi } \\
\text { Pengguna (Y) }\end{array}$ & \multicolumn{2}{|c|}{ Keberlanjutan dalam menggunakan aplikasi ini (C) } & (Kotler, 2009) \\
\hline
\end{tabular}

\section{Uji Validitas}

Pada penelitian ini digunakan uji validitas. Jumlah sampel pada pengumpulan data adalah 68. Untuk jumlah data 30 dengan taraf signifikan $5 \%$, diketahui nilai $\mathrm{r}$ tabel $=$ 0.361 . nilai $r$ tabel ini kemudian dibandingkan dengan $r$ hitung yang diperoleh dari output SPSS. Tabel 2 menunjukkan bahwa semua nilai $r$ hitung lebih besar daripada $r$ tabel sehingga dapat disimpulkan bahwa seluruh item kuesioner valid. 
Tabel 2.

Hasil Pengujian Validitas

\begin{tabular}{|c|c|c|c|}
\hline Kode & $\begin{array}{c}\mathrm{R} \\
\text { Hitung }\end{array}$ & R tabel & Ket \\
\hline KL1 & ,717 & 2012 & Valid \\
\hline KL2 & 746 & 2012, & Valid \\
\hline KL3 & 621 & 2012 & Valid \\
\hline KL4 & 716 & 2012 & Valid \\
\hline KL5 & 783 & 2012, & Valid \\
\hline KL6 & 727 & 2012 & Valid \\
\hline KL7 & ,436 & 2012, & Valid \\
\hline KL8 & 651 & 2012 & Valid \\
\hline KL9 & 730 & 2012, & Valid \\
\hline KL10 & 661 & 2012 & Valid \\
\hline LD1 & ,371 & 2012 & Valid \\
\hline LD2 & 392 & 2012, & Valid \\
\hline LD3 & 461 & 2012, & Valid \\
\hline LD4 & 651 & 2012, & Valid \\
\hline LD5 & 714 & 2012, & Valid \\
\hline LD6 & ,590 & 2012, & Valid \\
\hline LD7 &, 564 & 2012, & Valid \\
\hline LD8 & ,521 & 2012, & Valid \\
\hline LD9 & ,544 & 2012, & Valid \\
\hline LD10 & ,368 & 2012 & Valid \\
\hline TK1 & ,834 & 2012 & Valid \\
\hline TK2 & ,831 & 2012, & Valid \\
\hline TK3 & ,466 & 2012, & Valid \\
\hline TK4 & ,858 & 2012 & Valid \\
\hline TK5 & 794 & 2012, & Valid \\
\hline TK6 & 793 & 2012, & Valid \\
\hline TK7 & 777 & 2012, & Valid \\
\hline TK8 & 808 & 2012, & Valid \\
\hline TK9 & 729 & 2012, & Valid \\
\hline TK10 & ,754 & 2012 & Valid \\
\hline
\end{tabular}

\section{Uji Reliabilitas}

Tingkat reliabilitas variabel dinilai dari nilai Alpha Cronbach. Hasil pengukuran reliabilitas sebagaimana pada tabel 3 menunjukkan bahwa nilai Alpha Cronbach untuk seluruh variabel telah melebihi 0.6 sehingga dapat disimpulkan bahwa instrument yang disusun pada seluruh variabel telah reliabel. 
Tabel 3.

Hasil Pengujian Reliabilitas

\begin{tabular}{|c|c|c|}
\hline Variabel & $\begin{array}{c}\text { Alpha } \\
\text { Cronbach }\end{array}$ & Keterangan \\
\hline $\mathrm{X} 1$ & 0,911 & Reliabel \\
\hline $\mathrm{X} 2$ & 0,828 & Reliabel \\
\hline $\mathrm{Y}$ & 0,941 & Reliabel \\
\hline
\end{tabular}

\section{Profil Responden}

Jumlah kuesioner yang terkumpul pada tahap pengumpulan data utama adalah 100 kuesioner. Setelah dilakukan penyaringan data melalui karakteristik responden maka didapatkan 68 kuesioner dapat digunakan untuk pengolahan data selanjutnya. Profil responden ditampilkan pada tabel 4.

Tabel 4.

Profil Responden

\begin{tabular}{|c|c|c|c|}
\hline Indikator & & Jumlah & Persentase \\
\hline \multirow{2}{*}{ Jenis kelamin } & Laki-laki & 28 & $41.17 \%$ \\
\hline & Perempuan & 40 & $58.83 \%$ \\
\hline \multirow{2}{*}{ Usia } & $<20$ Tahun & 51 & $75 \%$ \\
\hline & 20-30 Tahun & 17 & $25 \%$ \\
\hline \multirow{2}{*}{$\begin{array}{c}\text { Pengetahuan } \\
\text { Aplikasi Tangerang } \\
\text { Live }\end{array}$} & Tahu & 22 & $32.36 \%$ \\
\hline & Belum Tahu & 46 & $67.64 \%$ \\
\hline \multirow{2}{*}{$\begin{array}{c}\text { Penggunaan } \\
\text { Aplikasi Tangerang } \\
\text { Live } \\
\end{array}$} & Pernah & 20 & $29.41 \%$ \\
\hline & Belum Pernah & 48 & $70.59 \%$ \\
\hline
\end{tabular}

\section{Kualitas Aplikasi Tangerang Live}

Berdasarkan profil responden pada tabel 4 diketahui bahwa sebagian besar responden $32.36 \%$ belum mengetahui adanya aplkasi Tangerang Live. Oleh karena itu, untuk menilai kualitas apliakasi Tangerang Live, sebelum responden tersebut memberikan penilaian, responden yang bersangkutan diberikan penjelasan tentang applikasi Tangerang Live serta diberikan kesempatan untuk mencoba melacak info lowongan kerja (Upload CV dan lain-lain) melalui aplikasi Tangerang Live. Setelah responden mengetahui fungsi dan telah mencoba sendiri kegunaan aplikasi Tangerang Live, selanjutnya diminta mengisi kuesioner. Hasil penilaian kualitas aplikasi Tangerang Live berdasarkan persepsi pengguna memberikan sebuah indikasi bahwa aplikasi Tangerang Live telah memiliki kualitas yang baik dilihat dari aspek 


\section{Pembahasan}

Skala SERVQUAL yang digunakan dalam penelitian ini sebenarnya merupakan teori yang diadopsi dari salah satu teori manajemen pemasaran (Leonard L Berry, A Parasuraman, dan Valerie A Zeithami, 2009) yang disesuaikan penggunaannya sebagai kerangka untuk mengukur faktor kualitas aplikasi berbasis smartphone. Hasil penelitian menunjukkan bahwa SERVQUAL masih cukup valid dan reliabel untuk mengukur kualitas layanan teknologi informasi dan komunikasi selain website.

Tabel 5.

Uji Regresi Linear Berganda

\begin{tabular}{|c|c|c|c|c|c|}
\hline \multirow[t]{2}{*}{ Model } & \multicolumn{2}{|c|}{$\begin{array}{l}\text { Unstandardized } \\
\text { Coefficients }\end{array}$} & \multirow{2}{*}{$\begin{array}{c}\begin{array}{c}\text { Standardi } \\
\text { zed } \\
\text { Coefficien } \\
\text { ts }\end{array} \\
\text { Beta }\end{array}$} & \multirow[t]{2}{*}{$\mathrm{t}$} & \multirow[t]{2}{*}{ Sig. } \\
\hline & B & $\begin{array}{l}\text { Std. } \\
\text { Error }\end{array}$ & & & \\
\hline (Constant) & 14.036 & 4.687 & & 2.995 & .004 \\
\hline 1 Kualitas Layanan & .373 & .101 & .434 & 3.704 & .000 \\
\hline Layanan Dasar & .272 & .137 & .232 & 1.979 & .052 \\
\hline
\end{tabular}

a. Dependent Variable: Tingkat Ketertarikan

Hasil regresi liniear berganda menujukkan bahwa pengguna berniat menggunakan aplikasi Tangerang Live karena didorong oleh faktor kualitas aplikasi. Hasil penelitian ini semakin memperkuat hasil penelitian sebelumnya yang dilakukan oleh (Santosa, 2019) menyatakan bahwa kepuasan konsumen dipengaruhi oleh faktor kualitas layanan dan layanan dasar dari produk yang terkait.

Namun demikian, meskipun menurut persepsi pengguna aplikasi Tangerang Live dinilai telah memiliki kualitas yang baik, aplikasi Tangerang Live ini belum banyak diketahui dan digunakan oleh pengguna. Berdasarkan profil responden pada tabel 4 , diketahui bahwa dari 68 responden hanya 22 orang $(32.36 \%)$ yang menyatakan telah mengetahui adanya aplikasi Tangerang Live. Dan dari 22 orang tersebut, hanya 20 orang yang menyatakan pernah menggunakan dan merasakan manfaat aplikasi Tangerang Live. Dan setelah responden diberikan sosialisasi singkat tentang aplikasi Tangerang Live dan diminta mengeksplorasi fitur-fitur di dalam aplikasi, responden menilai bahwa aplikasi Tangerng Live memiliki manfaat selain untuk mengecek status upload data identitas (untuk kebutuhan melamar kerja) juga mampu mengurangi nomor antrian dalam proses pelayanan publik yang dibutuhkan pada instansi terkait. 
Tabel 6.

Ringkasan Model

\begin{tabular}{|l|r|r|r|}
\hline $\mathrm{R}$ & \multicolumn{1}{|c|}{$\mathrm{R}^{2}$} & Adjusted R & Std. Error \\
\hline $.589^{\mathrm{a}}$ & .347 & .327 & 3.15059 \\
\hline
\end{tabular}

Regresi

(Irfan, 2017) juga berkesimpulan bahwa aplikasi Tangerang Live dinilai pengguna sangat bermanfaat dab mampu mendukung proses pelayanan publik. Aplikasi Tangerang Live merupakan salah satu bentuk perhatian Pemerintah Kota Tangerang bagi masyarakat Kota Tangerang dengan menyediakan teknologi pengecekan nomor antrian dan lain-lain pada proses pelayana publik. Perancangan aplikasi ini tentunya memerlukan investasi yang tidak sedikit. Karena itu perlu didorong agar aplikasi Tangerang Live ini dapat dimanfaatkan secara maksimal agar investasi pemerintah menjadi tidak sia-sia. Hal ini sejalan dengan analisis regresi linear berganda yang menyatakan bahwa variabel persepsi penggunaan (tingkat keberlanjutan) aplikasi Tangerang Live baru mampu menjelaskan variabel kualitas layanan sebesar $34.7 \%$ hal ini bearti masih terdapat variabel lain sebesar $65.3 \%$ yang belum bisa dibahas dalam model penelitian ini dan dapat dilakukan penelitian selanjutnya. Variabel lain tersebut salah satunya adalah sosialisasi mengenai keberadaan dan manfaat aplikasi Tangerang Live. Responden dalam penelitian ini menyatakan selama ini belum ada sosialisasi terkait aplikasi Tangerang Live padahal melalui sosialisasi, dapat disampaikan informasi mengenai aplikasi Tangerang Live kepada pengguna sehingga pengguna memahami manfaat dan cara penggunaan niat pengguna untuk menggunakan aplikasi tersebut.

\section{Kesimpulan}

Berdasarkan hasil pengukuran diatas diketahui bahwa kualitas layanan pada aplikasi Tangerang Live dilakukan dengan skala SERVQUAL yang sejatinya digunakan sebagai pengukuran pada dimensi jasa. Berbagai studi telah memperlihatkan bahwa perusahaan jasa yang dikelola dengan baik bersama-sama memiliki praktik konsep strategis, sejarah komitmen manajemen puncak terhadap kualitas, standar yang tinggi, teknologi, dan sistem untuk mengamati keluhan pelanggan.

Keandalan dalam penanganan masalah layanan pelanggan, layanan tepat waktu bagi pelanggan, membuat konsumen merasa aman dalam melakukan transaksi mereka, mengutamakan kepetingan terbaik pelanggan dan tampilan aplikasi yang tampak menarik secara visual, telah menjadi tolak ukur utama yang mewakili point keandalan, responsivitas, jaminan, empati dan wujud dalam skala SERVQUAL

Persepsi kualitas yang terdiri dari tiga variabel yaitu kualitas layanan, layanan dasar dan tingkat ketertarikan (keberlanjutan) terbukti memiliki pengaruh secara positif dan signifikan terhadap variabel niat pengguna untuk menggunakan kembali aplikasi Tangerang Live. Namun demikian, tiga variabel diatas tersebut baru bisa menjelaskan variabel kualitas layanan sebesar $34.7 \%$, sisanya $65.3 \%$ dijelaskan oleh variabel lain yang belum dicakup dalam model regresi linear 
berganda. Karena itu penelitian selanjutnya dapat sekiranya menambahkan variabel indpeenden lainnya yang dapat meningkatkan proporsi pengaruh variabel independen terhadap variabel dependen, dimana salah satu rekomendasi yang diberikan adalah dengan memasukkan ke dalam model regresi ialah variabel sosialisasi.

\section{Daftar Pustaka}

Aeliyah, I. (2014). Pengaruh Pelaksanaan Program Keselamatan dan Kesehatan Kerja (K3) Terhadap Kinerja Karyawan Pada Bagian Produksi Di PT. Garuda Mas Semesta (GAMATEX) Cimahi. 40.

Fitriani, N., Deoranto, P., \& Dania, W. A. (2013). Analisis Pengaruh Keselamatan dan Kesehatan Kerja (K3) Terhadap Produktivitas Tenaga Kerja. Jurnal Industri, 95. https:/ / peraturan.bkpm.go.id. (2011, November 22).

https:/peraturan.bkpm.go.id/jdih/userfiles/batang/MENPAN_63_2003.pdf. Dipetik Pebruari 17, 2019, dari https://peraturan.bkpm.go.id: https:/ / peraturan.bkpm.go.id

https://tangerangkota.bps.go.id. (2018, November 21). Jumlah Penduduk menurut Kecamatan di Kota Tangerang, 2017. Dipetik Juni 10, 2019, dari https://tangerangkota.bps.go.id: https:/ / tangerangkota.bps.go.id

https://tangerangkota.go.id. (2016, Agustus 17). Pemkot Tangerang Luncurkan Aplikasi Tangerang Live. Dipetik Mei 02, 2019, dari https:/ / tangerangkota.go.id: https:/ / tangerangkota.go.id

https://tangerangkota.go.id. (2019, Pebruari 21). Pengguna Aplikasi Tangerang LIVE telah Mencapai 49 Ribu Akun. Dipetik Maret 21, 2019, dari https://tangerangkota.go.id: https://tangerangkota.go.id

https://www.statista.com/. (2019, Mei 2). Number of available applications in the Google Play Store from December 2009 to March 2019. Dipetik Juni 19, 2019, dari https://www.statista.com/statistics/266210/number-of-availableapplications-in-the- google-play-store/: https:/ / www.statista.com/

Irfan, F. A. (2017, Oktober 01). Aplikasi Tangerang Live. Dipetik Juli 2019, 03, dari https://www.kompasiana.com:

https:// www.kompasiana.com/fauzanahmad/59d083659f63cd2e803bcf22/ aplikasi- tangerang-live

Keller, P. K. (2009). Manajemen Pemasaran. Jakarta: Erlangga.

Keller, P. K. (2009). Rekomendasi Untuk Meningkatkan Kualitas Jasa. Dalam P. K. Keller, Manajemen Pemasaran (hal. 44). Jakarta: Erlangga.

Kotler, P. (2009). Atribut SERVQUAL. Dalam K. L. Philip Kotler, Manajemen Pemasaran (hal. 52). Jakarta: Erlangga.

Leonard L Berry, A Parasuraman, dan Valerie A Zeithami. (2009). Ten Lessons For Improving Service Quality. Dalam P. K. Keller, Manajemen Pemasaran (hal. 44). Jakarta: Erlangga.

Pangestu, A. (2016). Pengaruh Program Keselamatan Dan Kesehatan Kerja (K3) Dan Disiplin

Kerja Karyawan Terhadap Produktivitas Kerja Karyawan. 63. 
Santosa, S. (2019). Kepuasan Konsumen Pengguna Kecap Merek "S.H. D/H Siong Hin" Sebagai Icon Ekonomi Masyarakat Benteng-Tangerang. Komunitas Dosen Indonesia, 152-160.

setkab.go.id. (2017, Oktober 9). Layanan Publik Kepolisian Harus Berbasis Digital. Dipetik Juni 19, 2019, dari http://presidenri.go.id: http:// presidenri.go.id/berita-aktual/layanan-publik- kepolisian-harusberbasis-digital.html

Sugiyono. (2013). Analisis Data Kuantitatif. Bandung: CV. Alfabeta Bandung. 